\title{
MINING
}

UDC 622.324 .5

V. I. Bondarenko, Dr. Sc. (Tech.), Prof., orcid.org/0000-0001-7552-0236,

K. S. Sai, Cand. Sc. (Tech.),

orcid.org/0000-0003-1488-3230
DOI: $10.29202 / \mathrm{nvngu} / 2018-2 / 4$

National Mining University, Dnipro, Ukraine, e-mail: kateryna.sai@gmail.com

\section{PROCESS PATTERN OF HETEROGENEOUS GAS HYDRATE DEPOSITS DISSOCIATION}

Purpose. Justification of the effective dissociation process parameters of heterogeneous gas hydrate deposits and elaboration of their classification according to the thermal energy consumption.

Methodology. The methodological basis of the conducted complex research is the analysis and synthesis of literary sources, devoted to studying the peculiarities and thermobaric properties of gas hydrates, analytical calculations and laboratory experiments on the thermal energy consumption for the efficient decomposition of gas hydrates, experimental studies of the hydrate formation process and gas hydrate deposits of the mottled structure dissociation.

Findings. The parameters of formation and stable gas hydrate occurrence in natural environment, which should be taken into account when developing gas hydrate deposits, are substantiated. The existing classification of gas hydrate deposits in sedimentary rocks is analyzed. The regularities of the gas hydrate deposits dissociation process and methane gas production, depending on the percentage of rock intercalations content, are established. The volumes of analysis zones and gas output from heterogeneous gas hydrate deposits are determined. The amount of thermal energy that is necessary to be consumed to produce $1000 \mathrm{~m}^{3}$ of hydrated gas during the gas hydrate deposits development, is calculated.

Originality. It is established that the thermal energy consumption on the dissociation process in order to obtain methane gas varies with a parabolic dependency with an increase in the rock intercalations proportion in the gas hydrate deposit. A new classification of gas hydrate deposits, based on the content of rock intercalations and the amount of spent thermal energy for gas hydrate dissociation, has been developed.

Practical value. The results of studies with sufficient accuracy for practical application may be used in the development of the Black Sea gas hydrate deposits in order to obtain natural gas. The revealed dependencies of the methane gas output on the rock intercalation share are a tool for determining the effective application of technologies for the gas hydrate deposit development.

Keywords: gas hydrate deposit, heterogeneity, classification, rock intercalations, dissociation, energy consumption

Introduction. The current trend in the development of coal, oil and gas production in Ukraine indicates the necessity of applying new approaches to the formation of a raw material base, such as allocation of alternative sources of hydrocarbon raw materials in a separate industrial branch. Being the most environmentally friendly utility product, natural gas will continue to play an important role in the energy supply and future development of the world's energy.

Alternative types of fuel gas include methane of coal deposits [1]; coalmine methane; gas obtained during the solid fuel processing (hardcoal (bituminous coal) and brown coal (lignite), shale coal (bituminous shale), bog muck (lignum fossile) [2]; gas contained in aquifers of oil and gas bearing basins with an abnormally high reservoir pressure, and in gas-saturated reservoirs and

(C) Bondarenko V. I., Sai K. S., 2018 marshes; biogas (RNG), exhaust gas, other fuel gas, obtained from biological raw materials; gas obtained from industrial wastes; gas deposits on the Moon [3]; as well as gas contained in gas hydrate deposits. Development and introduction of technologies for obtaining gas through underground coal gasification in complex mining-geological conditions [4] and in the multiple coal layers development [5] deserves particular attention.

Thus, the issue of deficit and reduction of energy resources, in particular natural gas, is becoming more and more relevant, which increases the interest in developing technologies of extracting new energy feedstock types, among which, according to the authors, the gas hydrates of the Black Sea bottom sediment are prospective.

The Black Sea aquatorium is characterized by the presence of gas hydrate deposits, the capacity of which, according to geologists and seismic survey results, reaches in average 700 meters from the surface of the sea 
bottom. The Ukrainian part of the sea has methane gas resources that can be extracted from gas hydrate deposits located directly opposite the Crimean peninsula, with the volume of $20-25$ trillion $\mathrm{m}^{3}$. The total forecast gas resources throughout the Black Sea amount to at least 100 trillion $\mathrm{m}^{3}$, based on the results of the intrusion and analysis of the studied core (1988-1989) [6]. The analysis of thermobaric conditions within the deep part of the Black Sea basin gives all grounds to assert that the available parameters of temperature and pressure at the depths of the sea 500-750 $\mathrm{m}$ are optimal for the formation of gas hydrate deposits in such conditions.

According to the data of regional seismic profiles on a $25 \times 25 \mathrm{~km}$ grid, carried out by the "Pivdenmorheo" association, a significant distribution of gas hydrate deposits within the deep sea part of the Black Sea was established. The most promising are the central, northeastern and northern parts of the sea, where attention should be paid to the gas extraction from gas hydrate deposits technologies development. Gas hydrate deposits in the central deep-water part of the Black Sea are relatively heterogeneous, and the sediment intercalations share in deposits is insignificant [7].

Taking into account the existing energy potential of gas hydrates and the possibility of using hydrated gas as an additional utility product, it is obvious that the development and searching of specific technological solutions for the efficient methane extraction from gas hydrate deposits is an urgent problem and needs urgent solution.

Analysis of the recent research and publications. Over the past decades, the interest to gas hydrate deposits technology development and extraction of methane has increased considerably, as evidenced by a large number of projects and an increase in security documents share, not only in Ukraine, but also throughout the world. Today, thousands of highly skilled specialists from many leading countries of the world such as Bulgaria, Canada, China, Germany, India, Japan, Norway, Russia, South Korea, Turkey, Ukraine, the United Kingdom and the USA are working on artificial and natural gas hydrates, as well as the development of hydrate and dissociation technologies.

Scientists of scientific and research institutes, advanced research laboratories, organizations and educational institutions work to develop gas-hydrated technologies and to create technological schemes for gas extraction from natural gas hydrates not only in the territory of our country, but also abroad. Particular attention in this scientific approach is to be drawn to the works of scientists of the National Mining University, Ivano-Frankivsk National Technical University of Oil and Gas, Kirovohrad National Technical University, Poltava National Technical University named after Yuri Kondratyuk, State Scientific Institution of the Marine Geology Department and Sedimentary Ore of the National Academy of Sciences of Ukraine, Institute of Gas of the National Academy of Sciences of Ukraine, Institute of Geophysics named after S.I. Subbotin of the Academy of Sciences of Ukraine, Oregon State University (USA), Colorado University (USA), Russian State
University of Oil and Gas named after I. M. Gubkin (Russia), University of Texas (USA), Research Center Marum (Germany), as well as world-renowned companies Chevron (USA), Conoco Phillips (USA), Japan Drilling (Japan), JAPEX (Japan), JOGMEC (Japan), Hydrate Energy International (USA), Mitsui (Japan) and others.

Vytiaz O. Yu., Horzyk P. F., Zotsenko M. L., Istomin V.A., Klymenko V.V., Kobolev V.P., Makogon Yu.F., Ovetskyi S.O., Pedchenko M.M., Smirnov L. F., Sniukov E. F., Yakushev V.S., Bishnoi P. R., Carrol J.J., Collet T.S., Dawe R., Handa Y.P., Martín M., Letcher T. M., Sloan E. D. and others have made a significant contribution to the development of gashydrated technologies and phase transitions study. They describe the properties and conditions of natural gas hydrate stability, consider the methods for gas hydrate deposits exploration [8], establish the parameters of gas hydrate and gas deposits development by binding free gas to gas hydrate [9], the involvement of the plumetectonic deep degassing mechanism on the Coalfields genesis of the Black Sea basin [10], phase transitions of the hydration process and dissociation in the gas hydrate deposits development containing the proportion of sedimentary rocks in the deposit were investigated [11], the basic processes of the method for gas hydrate extraction from the productive layer without the energy consumption of the phase transition on the basis of borehole hydro production were substantiated [12]. The study of the crystalline structure of gas hydrate, depending on the chemical composition of the reacting components by applying the method of raster electron microscopy [13] and substantiation into parameters of the process of gas hydrate deposits dissociation due to computer modeling with finite element method deserves particular attention [14].

Formation and accumulation features of gas hydrates in natural conditions. The accumulation of gas hydrate, as a rule, does not occur in a free area as sea water, but in a bottom rocks array. An important role in the process of natural gas hydrate formation is given to the parameters of pressure and temperature, as well as the properties and characteristics of the nature, in which the process of hydration formation and subsequent hydrate accumulation actually takes place.

The capacity of the gas-hydrated layers varies from hundreds of meters (when the deposits are located at a negligible depth (less than $500 \mathrm{~m}$ )) to $1 \mathrm{~km}$ or more (when the deposits are located at great depths). A constant companion and a source of natural gas hydrates may be a free gas under the gas hydrate deposit. In some areas of the bottom sediments, its concentration is so high that it begins to penetrate into the free openings between the rock particles. Since the gas hydrates accumulate in sedimentary rocks, these rocks become impenetrable. A closed space is formed which is capable of automatic sealing, in which the gas, which aspires to rise up, is accumulated. The more free gas penetrates into the hydration zone, the stronger gas hydrate deposits become. After full saturation of the gas hydrate layer, free gas can already accumulate under it. 
The lower line of gas hydrate deposits occurrence is determined by the geothermal gradient in the bottom sediments. For about $99 \%$ of gas hydrate reserves are found in seas and oceans. In conditions of land there is also a necessary thermobaric combination of pressure and temperature, suitable for the formation of natural gas hydrates and its homologues. It is worth noting that in continental rocks there is less water and less free space in which crystalline hydrates are formed.

It was established that gas hydrate deposits in rocks exist in the form of the following cryogenic structures: massive (in sandy soils); porphyric (in sandy loamy soils); schlier-lens-shaped (in clay soils).

Gas hydrates can be cement (concrete) or just fill the openings without cementing the grains of the sedimentary deposits. Strengthening of sedimentary rocks occurs due to the presence of hydrates in them, the role played by cement. Also, gas hydrates may exist in the pore space, without noticeably affecting the hardness and strength of sedimentary rocks. The formation of gas hydrates in the seas in the conditions of the bottom rocks allows the filling of the existing openings not with water, but with hard gas hydrated skeleton.

In order to assess the energy potential of gas hydrates, it is important to determine possible variants of their location in the sedimentary layer and to establish the properties of the hydrated layers. After analyzing the existing data on the findings of gas hydrates in the Earth's crust, we can conclude that gas hydrates exist in rocks in the form of bird-shot concretion, strands, veinlets and massive layers.

The formation of gas hydrates in sediment deposits occurs in two different hydrate-accumulation variants:

- the first one occurs when the gas hydrates are formed and accumulated on the contacts of the rock particles, which leads to the cementation of the sedimentary deposits skeleton;

- the second one occurs when the formation of gas hydrates takes place directly in openings and pores. According to this embodiment, it is obvious that the hydrates practically do not affect the connection of the rock particles, which leads to the thickening of the sedimentary strata.

In bottom sediments, in addition to gas hydrates, gas in free state, water and even ice may also be available (which is a characteristic feature of cryolithozone). Therefore, V.S. Yakushev has proposed the classification of gas hydrated deposits, depending on the phase state of the pore fluids:

- gas hydrated rocks, in which mineral particles, organic matters and gas are included in the massive gas hydrated layer;

- gas-gas hydrated rocks, in the openings of which gas hydrates and gas are located, and there is no free water;

- water-gas hydrated rocks, in the openings of which there are gas hydrates and water, but there is no free gas;

- water-gas-gas hydrated rocks contain gas hydrates, gas and water in openings;

- ice-gas hydrated rocks, in openings gas hydrates, gas and ice are contained, but there is no free gas and water;
- ice-gas-gas hydrated rocks, in openings gas hydrates, free gas and ice are contained, but there is no free water;

- ice-water-gas hydrated rocks, in openings gas hydrates, ice and water are contained, but there is no gas;

- ice-water-gas-gas hydrated rocks, in openings both gas hydrates and gas, water and ice are contained.

Perlova E. V. and Yakushev V.S. developed a classification of gas hydrates on the basis of genetic features. Thus, there are three types of gas hydrate deposits: submarine deposits of gas hydrates; continental stable deposits of gas hydrates; continental metastable deposits of gas hydrates.

The basic principle of a submarine gas hydrate deposits type formation is the significant bio-chemical methane gas release and its migration to the zone of gas hydrate stability. A characteristic feature of the submarine deposits is their confinement to the aquatorium, which is characterized by a maximum content of organic matter and intense activity of methanobacteria.

The places of continental stable gas hydrate formation include islands and continents, taking into account the zone of gas hydrate stability. Since the gas hydrated layers formation is possible under the existing oil and gas deposits, the source for their accumulation is thermogenic gas and gas of biochemical origin from the below-placed oil and gas collectors. Another way of continental stable deposit occurrence is converting a gas field into a gas hydrate due to the thermobaric parameters change in the rock layer.

Continental metastable gas hydrate deposits are represented by clusters of relic gas hydrates, which have got their name due to their self-preservation formation and the possibility of existence beyond the gas hydrate structures stability zone. The gas hydrate metastability zone is considered as all thickness of permafrost rocks from the bottom of the seasonal thaw layer to the permafrost bottom, in which the temperature of the array does not exceed the temperature of soils thawing.

According to T.S. Collett, geological and geophysical characteristics of gas hydrate deposits finding in sedimentary rocks can be a sign that these deposits are divided into three types. The first type includes gas hydrated deposits, under which there is natural gas in free form. The equilibrium line of hydrate formation for the first type coincides with the gas hydrate deposit bottom. The second type is gas hydrate deposits, under which there is an interbedded water. The third type includes deposits that lie between the rocks, which have no free gas or free water underneath [15].

Another classification of gas hydrate deposits, based on thermobaric conditions of the gas hydrate occurrence in the subsoil, is proposed by Yu. F. Makogon. According to this classification, gas hydrate deposits are divided into types depending on the temperature in the rock section. Gas hydrate deposits in permafrost rocks; overcooled deposits that exist at shallow depths; and high-temporal deposits adjacent to the lower boundary of the hydrates stability zone are distinguished [16].

Maksymova E.O. distinguishes 5 types of gas hydrate deposits, depending on the material content of the 
rocks, geological structures and their filtering properties [17]:

- type 1 - integrity deposits at the bottom of the seas and oceans, in the zones of the shelf and cavities, as well as large tectonic faults (amorphous deposits of gas hydrates in the form of pure ice);

- type 2 - integrity rock mass deposits from practically homogeneous line grain gas hydrated arrays occurring in the zones of shelf and marine and oceanic cavities, mainly in sands, coarse-grained, fractured cataclasts;

- type 3 - gas hydrate deposits confined to sandy and loamy deposits, with pores saturated with gas hydrate;

- type 4 - gas hydrate deposits in brecciformed clastic rocks;

- type 5 - deposits in the form of veins formed in large massifs of igneous rocks, along normal faults and strike slips (deposits have a mixed structure: from brecciform, fine-grained to amorphous).

Unsolved aspects of the problem. The structure of hydrate-containing deposits differs from the ordinary ones. In the first ones besides mineral (rock) skeleton there are also gas hydrates that affect the properties of the rock [18]. Investigations show that gas hydrates can be used as a small part of the pore space, in which, along with them, there is free gas and water, and they can also fill the openings completely. Partial filling of the pore space of rocks with gas hydrates is due to the fact that the filtration of gas from the bowels of the earth through tectonic faults and fractures is complicated due to the preformation of gas hydrates, and the process of hydration formation is ceased.

Existing data on the formation and accumulation conditions of gas hydrates, materials provided by the Institute of Geological Sciences of the National Academy of Sciences of Ukraine, as well as the results of the wells drilled core analysis, made it possible to conclude that gas hydrates are in the bottom sediments of the Black Sea at appropriate thermobaric parameters that meet conditions of stable existence of gas deposits, not only in the form of pure hydrated layers, but, more often, with rock intercalations, which make the structure of the deposit heterogeneous. Available technological solutions for methane gas extracting from gas hydrate deposits for the Black Sea conditions, which include the bottom rock intercalations, have not been studied sufficiently. Therefore, issues related to the parameters substantiation of an effective dissociation process of heterogeneous gas hydrate deposits and methane gas extraction are urgent and need to be solved.

The objective of this work is to develop a classification of gas hydrate deposits, taking into account the established parameters of an effective process of gas hydrates decomposition with a variable rock intercalation share to obtain methane gas based on analytical and experimental studies results in the development of heterogeneous gas hydrate deposits.

To achieve this purpose, the following tasks were solved:

- analysis of existing classifications of gas hydrate deposits and detection of their formation mechanism;
- pursuance of the experimental research of the hydration formation process and gas hydrate decomposition with a variable proportion of rock intercalations;

- determination of decomposition zones volumes of formed heterogeneous gas hydrate deposits and methane gas from the rock intercalations;

- installation of heat energy consumption for obtaining $1000 \mathrm{~m}^{3}$ of gas in the gas hydrate deposit development, taking into account the rock intercalation share in the deposit.

Results of research studies. Experimental studies of the hydration process were carried out based on the NPO-5 laboratory setup, placed in a climacteric chamber ILKA KTK-3000 [19]. Determination of the decomposition parameters of formed gas hydrate deposits and methane gas volume that was allocated at the same time, were carried out with the help of a laboratory setup designed for the dissociation process study [20].

Conducting laboratory research was aimed at the creation of pure gas hydrate samples and gas hydrates with a variable proportion of rocky aluminosilicate rock intercalations of marine sediments (inhomogeneous structures), followed by their decomposition in order to establish the regularities of the process of obtaining natural gas, depending on the rock intercalations content. In general, the methodology of laboratory studies included the preparation of samples for physical modeling, the pursuance of several experiments and the processing of experimental data [19]. The gas hydrate production was the first stage of research, followed by the ones, devoted to determining the parameters of hydrate decomposition and methane gas extraction.

According to the conducted analytical and laboratory studies, it was established that the volume of the decomposition zone of the formed gas hydrate deposit with the rock intercalations share change within $1.1 \cdot 10^{-3}$ to $6.9 \cdot 10^{-3} \mathrm{~m}^{3}$. In real conditions, taking into account the scale factor, this volume ranged from 1098 to $6879 \mathrm{~m}^{3}$, depending on the number of rock intercalations in gas hydrate. Changing the methane gas output at deposit dissociation, according to analytical and laboratory studies, is presented in Fig. 1. The output of

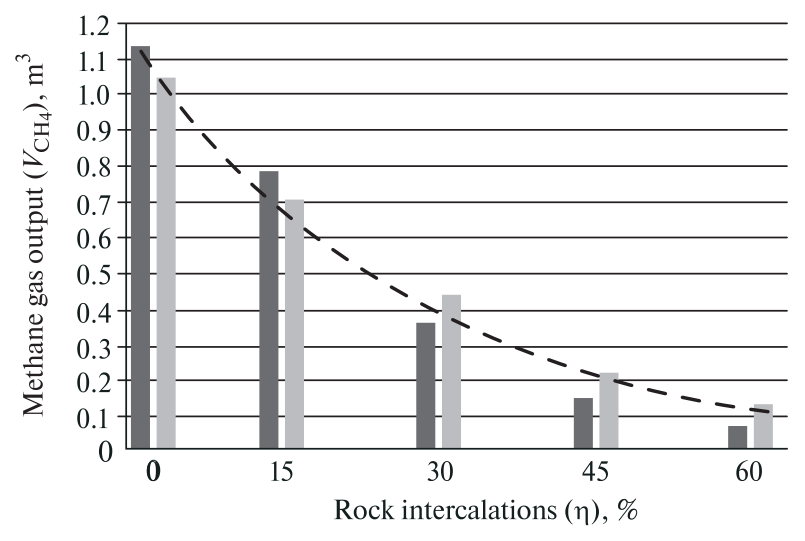

Fig. 1. Methane gas output dependence on the rock intercalation share:

- data according to laboratory studies; $\square-$ data according to analytical researches 
methane at the gas hydrate deposit decomposition varied with exponential dependence, taking into account the rock intercalations share

$$
V_{\mathrm{CH}_{4}}=1.17 e^{-0.04 \eta} ; \quad R^{2}=0.97 .
$$

The thermal energy consumption in relation to real conditions was determined in two ways - analytical and laboratory ones, on the basis of the average methane gas output determination from the decomposition zone of gas hydrate deposit with a variable rock intercalation share.

In order to ensure an effective dissociation process of gas hydrate deposit with a variable rock intercalation share it is necessary, first of all, to determine the amount of thermal energy consumption used to decompose it.

The analytical determination of the energy consumption was made for $1 \mathrm{~m}^{3}$ of gas hydrate deposit as follows:

- spent thermal energy on the melting process $\left(Q_{1}\right)$

$$
Q_{1}=\lambda \cdot m_{g . h .},
$$

where $\lambda$ is the specific heat of gas hydrate melting; $\lambda=$ $=471.96 \mathrm{~kJ} / \mathrm{kg} ; m_{\text {g.h. }}$ is mass of gas hydrate, $\mathrm{kg}$;

- spent thermal energy of the dehydration zone $\left(Q_{2}\right)$

$$
Q_{2}=c_{g . h^{*}} \cdot m_{g . h^{*}} \cdot \Delta T=c_{g . h^{*}} \cdot m_{g . h^{*}} \cdot\left(T_{u t . p^{*}}-T_{\text {nat }}\right),
$$

where $c_{\text {g.h. }}$ is specific heat capacity of the gas hydrated deposit, $c_{g . h}=3.2 \mathrm{~kJ} / \mathrm{kg}^{\circ} \mathrm{C} ; \Delta T$ is temperature difference; $T_{\text {ut.p. }}$ is temperature of utility product; $T_{n a t}$ is temperature of deposit in natural conditions; $\Delta T=12-8=$ $=4{ }^{\circ} \mathrm{C}$;

- thermal energy consumption for the rock intercalations heating

$$
Q_{3}=c_{r . i .} \cdot m_{r . i .} \cdot \Delta T=c_{\text {r.i. }} \cdot m_{\text {r.i. }} \cdot\left(T_{\text {ut.p. }}-T_{\text {nat }}\right),
$$

where $c_{r . i .}$ is specific heat of rock intercalations; $c_{r . i .}=$ $=0.7 \mathrm{~kJ} / \mathrm{kg}{ }^{\circ} \mathrm{C} ; m_{\text {r.i. }}$ is mass of rock intercalations, $\mathrm{kg}$.

The total thermal energy for pure gas hydrate decomposition will be

$$
Q=Q_{1}+Q_{2} .
$$

For decomposition of gas hydrate deposits of mottled structure with a rock intercalation share, the total thermal energy will be calculated as

$$
Q=Q_{1}+Q_{2}+Q_{3} .
$$

Consequently, for $1 \mathrm{~m}^{3}$ of pure gas hydrate decomposition, it is necessary to consume $429.5 \mathrm{MJ}$ of thermal energy, which makes it possible to obtain $164 \mathrm{~m}^{3}$ of methane gas. Then, to receive $1000 \mathrm{~m}^{3}$ of methane gas, it is necessary to spend $2618.9 \mathrm{MJ}$ of energy.

According to the determination of thermal energy by experimental method, firstly a total amount of methane gas output from decomposition zone, which varied depending on the proportion of rock intercalations and volumes of this zone at a special laboratory setup were found. The obtained data formed the basis of the following formulas:

- for a heterogeneous gas hydrate deposit containing no rock intercalations

$$
\begin{gathered}
Q=\lambda \cdot m_{\text {g.h. }}+c_{\text {g.h. }} \cdot m_{\text {g.h. }} \cdot \Delta T= \\
=\lambda \cdot V_{\text {g.h. }} \cdot \rho_{\text {g.h. }}+c_{\text {g.h. }} \cdot V_{\text {g.h. }} \cdot \rho_{\text {g.h. }} \cdot\left(T_{\text {ut.p. }}-T_{n a t}\right),
\end{gathered}
$$

where $V_{g . h}$ is the volume of gas hydrate deposit of mottled structure, $\mathrm{m}^{3} ; \rho_{\text {g.h. }}$ is the thickness of gas hydrate deposit, $\mathrm{kg} / \mathrm{m}^{3}$;

- for a gas hydrate deposit of mottled structure containing a certain rock intercalations share

$$
\begin{gathered}
Q=\lambda \cdot m_{g . h .}+c_{g . h .} \cdot m_{g . h .} \cdot \Delta T+ \\
+c_{r . i .} \cdot m_{r . i .} \cdot \Delta T=\lambda \cdot\left(V_{g . h .}-V_{g . h .} \cdot \frac{\eta_{\text {r.i. }}}{100}\right)+ \\
+c_{g . h .} \cdot\left(V_{g . h .}-V_{\text {g.h. }} \cdot \frac{\eta_{\text {r.i. }}}{100}\right)+c_{\text {r.i. }} \cdot V_{\text {g.h. }} \cdot \frac{\eta_{\text {r.i. }}}{100},
\end{gathered}
$$

where $\eta_{\text {r.i. }}$ is percentage of rock intercalations, $\%$.

In this case, the total methane gas output from each formed decomposition zone volume of gas hydrate deposit was determined by the following formula:

- for a heterogeneous gas hydrate deposit containing no rock intercalations

$$
V_{\mathrm{CH}_{4}}=\frac{V_{d . z .}}{V_{d . z .}^{l a b}} \cdot V_{\mathrm{CH}_{4}}^{l a b},
$$

where $V_{d . z}$ is the decomposition zone volume of the gas hydrate deposit in real conditions, $\mathrm{m}^{3} ; V_{d . z}^{l a b}$ is the decomposition zone volume of the gas hydrate deposit in laboratory tests, $\mathrm{m}^{3} ; V_{\mathrm{CH}_{4}}^{l a b}$ is received methane gas output in laboratory tests, $\mathrm{m}^{3}$;

- for a gas hydrate deposit of mottled structure containing a certain rock intercalation share

$$
V_{\mathrm{CH}_{4}}^{r . i .}=\frac{V_{d . z .}-V_{d . z \cdot} \cdot \frac{\eta_{r . i .}}{100}}{V_{d . z .}^{l a b} \cdot V_{C H_{4}}^{l a b}} .
$$

The results are shown in Table 1.

Consequently, after analyzing the data, obtained for energy consumption of gas hydrate deposits decomposition with a variable share of rock intercalations, and gas output from the formed zones of decompose deposits, the required amount of thermal energy to be consumed in order to obtain $1000 \mathrm{~m}^{3}$ of methane gas by the following formula was established

$$
Q_{1000}=\frac{Q}{V_{\mathrm{CH}_{4}}} \cdot 1000,
$$

Table 1

Decomposition zone volume and gas output from gas hydrate deposits

\begin{tabular}{|l|c|c|c|c|c|}
\hline $\begin{array}{c}\text { Rock intercalation } \\
\text { share, \% }\end{array}$ & 0 & 15 & 30 & 45 & 60 \\
\hline $\begin{array}{l}\text { Decomposition } \\
\text { zone volumes in } \\
\text { real conditions, } \mathrm{m}^{3}\end{array}$ & 6879 & 5422 & 3001 & 1802 & 1098 \\
\hline $\begin{array}{l}\text { Total methane gas } \\
\text { output, million } \mathrm{m}^{3}\end{array}$ & 1.030 & 0.563 & 0.287 & 0.132 & 0.050 \\
\hline
\end{tabular}


where $V_{\mathrm{CH}_{4}}$ is total methane gas output, million $\mathrm{m}^{3} ; Q$ is the amount of heat for the formation of a decompose gas hydration deposit in natural conditions.

The obtained results are presented in Fig. 2. A required amount of thermal energy to produce $1000 \mathrm{~m}^{3}$ of methane gas, depending on the proportion of rock intercalations, contained in the gas hydrate deposit, will be as follows

$$
Q_{1000}=0.80 \eta^{2}+20.27 \eta+3012.61 ; \quad R^{2}=0.97 .
$$

It has been found that thermal energy consumption, which is essential for $1000 \mathrm{~m}^{3}$ of methane gas production, is being increased with parabolic dependence with an increase in rock intercalation proportion in the gas hydrate deposit.

The established quantitative dependence makes it possible to determine the expediency of developing natural gas hydrate deposits of mottled structure, as well as to develop their classification according to energy consumption with a variable rock intercalations share in them.

Classification of gas hydrate deposits based on the rock intercalation content and energy consumption during their dissociation. Taking into account the peculiarities of hydrate accumulation in the bottom sediments of the Black Sea, a classification of gas hydrate deposits based on the rock intercalation content in these deposits has been developed. The basis of the classification is energy consumption in the gas hydrate deposit development to produce $1000 \mathrm{~m}^{3}$ of methane gas. Thus, it is proposed to divide the gas hydrates into 4 classes depending on the amount of rock intercalations in the gas hydrate array (Table 2).

I class of heterogeneity. It is assumed that this type of gas hydrate deposits contains up to $15 \%$ of intercalations, but they will not significantly affect the conditions of development. Such deposits are considered to be almost homogeneous, since the number of intercalations does not exceed a certain limit, after which they can no longer be considered as structurally gas hydrate intercalations. In this case, the gas hydrate itself becomes the main element and exists in the form of a homogeneous gas hydrate structure.

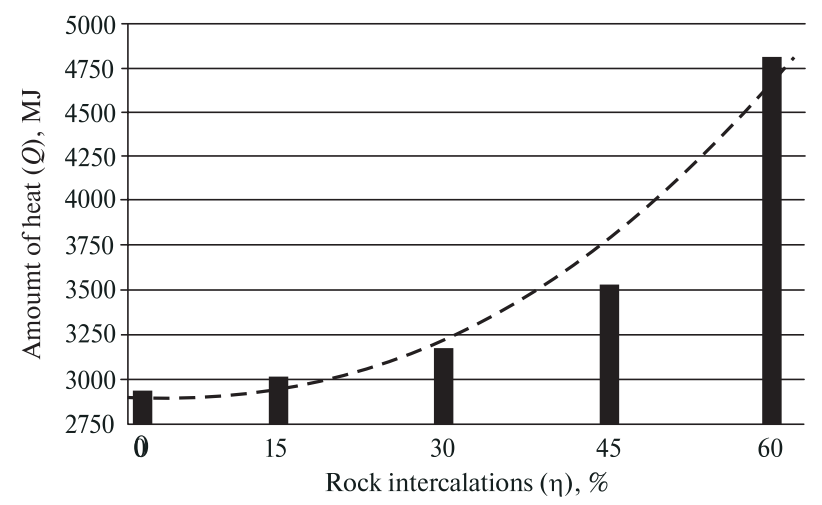

Fig. 2. Dependence of thermal energy consumption on $1000 \mathrm{~m}^{3}$ of methane gas production, depending on the rock intercalation share
Table 2

Classification of gas hydrate deposits according to energy consumption

\begin{tabular}{|c|l|c|c|}
\hline Class & Title & $\begin{array}{c}\text { Rock } \\
\text { intercalations } \\
\text { content }(\eta), \%\end{array}$ & $\begin{array}{c}\text { Amount of heat } \\
\text { on } 1000 \mathrm{~m}^{3} \\
\text { of methane } \\
\text { production }\end{array}$ \\
\hline I & $\begin{array}{l}\text { Almost } \\
\text { homogeneous }\end{array}$ & $\leq 15$ & $\leq 3007.25$ \\
\hline II & Heterogeneous & $\leq 30$ & $\leq 3269.23$ \\
\hline III & $\begin{array}{l}\text { Extremely } \\
\text { heterogeneous }\end{array}$ & $\leq 45$ & $\leq 3549.14$ \\
\hline IV & $\begin{array}{l}\text { Significantly } \\
\text { heterogeneous }\end{array}$ & $\leq 60$ & $\leq 4764.42$ \\
\hline
\end{tabular}

II class of heterogeneity. This type of gas hydrate deposits is the most common in nature, contains from 16 to $30 \%$ of rock intercalations in its structure. It is characterized by intense gas output during dissociation of gas hydrate. The deposits are gas hydrated arrays of significant power (sometimes up to $400 \mathrm{~m}$ ).

III class of heterogeneity. The gas output during the development of this type of gas hydrate deposits is somewhat smaller than in the development of the II class deposits, as they contain from 31 to $45 \%$ of rock minerals intercalations in their composition.

IV class of heterogeneity. The content of intercalations for this type of gas hydrate deposits ranges from 46 to $60 \%$. It is obvious, that almost half of the gas hydrate deposit contains rock particles. The gas output in the process of gas hydrate deposits developing of this class will be the smallest.

Based on the above classification, the development of gas hydrate deposits of the I-III classes is the most expedient, as the level of gas output in them is much higher than in the IV class deposits but obtaining gas from these deposits is also possible taking into account the relevant development parameters.

\section{Conclusions.}

1. The conditions of the gas hydrate deposits existence in the Black Sea area according to the results of geological and geophysical data have been analyzed and it was established that gas hydrates occur not only in the form of pure hydrate layers, but also contain rock intercalations, which makes the structure of the deposit heterogeneous.

2. Laboratory studies of the hydrate formation and dissociation process have been carried out and gas hydrates of the mottled structure with the content from 0 to $60 \%$ rock intercalations have been obtained.

3. The volumes of decomposition zones of the formed gas hydrate deposits with a variable rock intercalation share and the volumes of methane output during the dissociation of these deposits have been determined. It was established that the gas output during the gas hydrate decomposition varied exponentially depending on the proportion of rock intercalations. 
4. The amount of thermal energy, which is necessary for gas hydrates deposits decomposition, is calculated with a certain rock intercalation share in order to receive $1000 \mathrm{~m}^{3}$ of methane gas. The regular changes of thermal energy consumption amount for gas hydrate deposit decomposition of mottled structure by the rock intercalation share contained in them is obtained. It was established that the energy consumption for obtaining $1000 \mathrm{~m}^{3}$ of methane from the gas hydrate is increased due to parabolic dependence with an increase in the percentage of rock intercalations in the deposit.

5. The classification of gas hydrate deposits of mottled structure based on the rock intercalation content in gas hydrate, the classification basis of which is the amount of heat, consumed for the process of dissociation, was developed.

Acknowledgements. The presented results were obtained in the framework of the complex implementation of research papers GP-473 "Development of scientific principles of phase transformations of technogenic and natural gas hydrates and creation of the newest technologies of their extraction" (State registration No. 0115U002294) and GP-487 "Scientific substantiation and development of energy saving and low waste technologies of hydrocarbon and mineral raw materials extraction" (State registration No. 0116U008041).

\section{References.}

1. Hanushevych, K. and Srivastava, V., 2017. Coalbed methane: places of origin, perspectives of extraction, alternative methods of transportation with the use of gas hydrate and nanotechnologies. Mining of Mineral Deposits [e-journal], 11(3), pp. 23-34. DOI:10.15407/ mining 11.03.023.

2. Bondarenko, V. I., Kharin, Ye. N., Antoshchenko, N. I. and Gasyuk, R. L., 2013. Basic scientific positions of forecast of the dynamics of methane release when mining the gas bearing coal seams. Naukovyi Visnyk Natsionalnoho Hirnychoho Universytetu, 5, pp. 24-30.

3. Slyuta, E., 2017. Problems of research and mining of gas deposits on the Moon. Mining of Mineral Deposits [e-journal], 11(4), pp. 117-125. DOI: 10.15407/mining 11.04.117.

4. Lozynskyi, V.H., Dychkovskyi, R.O., Falshtynskyi, V.S. and Saik, P. B., 2015. Revisiting possibility to cross disjunctive geological faults by underground gasifier. Naukovyi Visnyk Natsionalnoho Hirnychoho Universytetu, 4, pp. 22-27.

5. Dychkovskyi, R. O., Lozynskyi, V.H., Saik, P. B., Petlovanyi, M. V., Malanchuk, Ye.Z. and Malanchuk, Z. R., 2018. Modeling of the disjunctive geological fault influence on the exploitation wells stability during underground coal gasification. Archives of Civil and Mechanical Engineering [e-journal], 18(3), pp. 845-860. DOI: 10.1016/j.acme.2018.01.012.

6. Merey, S. and Sinayuc, C., 2016. Investigation of gas hydrate potential of the Black Sea and modelling of gas production from a hypothetical Class 1 methane hydrate reservoir in the Black Sea conditions. Journal of Natural Gas Science and Engineering, 29, pp. 66-79.
7. Shnyukov, E. F., 2013. Mud volcanoes of the Black Sea as a prospecting indicator of methane gas hydrates. Lithology and Mineral Resources [e-journal], 48(2), pp. 114-121. DOI: 10.1134/s0024490213010045.

8. Makogon, Y.F. and Makogon, T. Y., 2016. Natural Gas Hydrates. Exploration and Production of Petroleum and Natural Gas [e-journal], pp. 429-459. DOI: 10.1520/mnl7320140017.

9. Pedchenko, M. and Pedchenko, L., 2016. Technological complex for production, transportation and storage of gas from the offshore gas and gas hydrates field. Mining of Mineral Deposits [e-journal], 10(3), pp. 2030. DOI: $10.15407 /$ mining 10.03.020.

10. Kobolev, V., 2017. Structural, tectonic and fluiddynamic aspects of deep degassing of the Black Sea megatrench. Mining of Mineral Deposits, 11/1, pp. 3149. DOI:10.15407/mining11.01.031.

11. Martín, M., 2016. Nonconventional fossil energy sources: shale gas and methane hydrates. Alternative Energy Sources and Technologies [e-journal], pp. 3-16. DOI: 10.1007/978-3-319-28752-2_1.

12. Pedchenko, M. and Pedchenko, L., 2017. Analysis of gas hydrate deposits development by applying elements of hydraulic borehole mining technology. Mining of Mineral Deposits [e-journal], 11(2), pp. 52-58. DOI: 10.15407/mining 11.02.052.

13. Kuz'menko, O., Petlyovanyi, M. and Stupnik, M., 2013. The influence of fine particles of binding materials on the strength properties of hardening backfill. Mining of Mineral Deposits [e-journal], pp. 45-48. DOI: 10.1201/b16354-10.

14. Kovalevs'ka, I., Symanovych, G. and Fomychov, V., 2013. Research of stress-strain state of cracked coalcontaining massif near-the-working area using finite elements technique. Annual Scientific-Technical Collection - Mining of Mineral Deposits [e-journal], pp. 159163. DOI: 10.1201/b16354-28.

15. Collett, T.S., 2013. Gas hydrate reservoir properties. In: Proceedings Unconventional Resources Technology Conference, Denver, Colorado.

16. Makogon, Y. F. and Omelchenko, R. Y., 2013. Commercial gas production from Messoyakha deposit in hydrate conditions. Journal of Natural Gas Science and Engineering [e-journal], 11, pp. 1-6. DOI: 10.1016/ j.jngse.2012.08.002.

17. Bondarenko, V., Maksymova, E. and Koval, O., 2013. Genetic classification of gas hydrates deposits types by geologic-structural criteria. Annual ScientificTechnical Collection - Mining of Mineral Deposits [ejournal], pp. 115-119. DOI: 10.1201/b16354-21.

18. Lozynskyi, V., Saik, P. and Petlovanyi, M., 2018. Analytical research of the stress-deformed state in the rock massif around faulting. International Journal of Engineering Research in Africa, 35, pp. 140-151.

19. Ovchynnikov, M., Ganushevych, K. and Sai, K., 2013. Methodology of gas hydrates formation from gaseous mixtures of various compositions. Annual Scientific-Technical Collection - Mining of Mineral Deposits [ejournal], pp. 203-205. DOI: 10.1201/b16354-37.

20. Bondarenko, V., Svietkina, O. and Sai, K., 2017. Study of the formation mechanism of gas hydrates of 
methane in the presence of surface-active substances. Eastern-European Journal of Enterprise Technologies [ejournal], 5-6(89), pp. 48-55. DOI: 10.15587/17294061.2017.112313.

\section{Закономірності процесу дисоціації неоднорідних газогідратних покладів}

\section{В. І. Бондаренко, К. С. Сай}

Державний вищий навчальний заклад „Національний гірничий університет“, м. Дніпро, Україна, e-mail: kateryna.sai@gmail.com

Мета. Обгрунтування параметрів ефективного процесу дисоціації неоднорідних газогідратних покладів і розробка їх класифікації за затратами теплової енергії.

Методика. Методичною основою проведених комплексних досліджень є аналіз і узагальнення літературних джерел, присвячених вивченню особливостей і термобаричних властивостей газових гідратів, аналітичні розрахунки й лабораторні експерименти щодо затрат теплової енергії для ефективного розкладання газогідратів, експериментальні дослідження процесу гідратоутворення й дисоціації газогідратних покладів неоднорідної структури.

Результати. Обгрунтовані параметри формування й стабільного існування газогідратів у природних умовах, що необхідно враховувати при розробці газогідратних родовищ. Проаналізовані існуючі класифікації покладів газових гідратів в осадових породах. Встановлені закономірності процесу дисоціації газогідратних покладів і одержання газу метану в залежності від процентного вмісту породних включень. Визначені об'єми зон розкладання й вихід газу із неоднорідних газогідратних покладів. Розрахована кількість теплової енергії, що необхідно затратити для одержання $1000 \mathrm{~m}^{3}$ гідратного газу при розробці газогідратних родовищ.

Наукова новизна. Встановлено, що затрати теплової енергії на протікання процесу дисоціації для одержання газу метану змінюються за параболічною залежністю зі збільшенням частки породних включень у газогідратному покладі. Розроблена нова класифікація газогідратних покладів за вмістом породних включень і кількістю затраченої теплової енергії на дисоціацію газогідрату.

Практична значимість. Результати досліджень із достатньою для практичного застосування точністю можуть використовуватися при розробці газогідратних родовищ Чорного моря з метою отримання природного газу. Виявлені залежності виходу газу метану від частки породних включень є інструментарієм для визначення ефективної області застосування технологій розробки покладів газових гідратів.

Ключові слова: газогідратний поклад, неоднорідність, класифікація, породні включення, дисоціація, затрати енергіi

\section{Закономерности процесса диссоциации неоднородных газогидратных залежей}

\section{В. И. Бондаренко, Е. С. Сай}

Государственное высшее учебное заведение „Национальный горный университет“, г. Днепр, Украина, e-mail: kateryna.sai@gmail.com

Цель. Обоснование параметров эффективного процесса диссоциации неоднородных газогидратных залежей и разработка их классификации по затратам тепловой энергии.

Методика. Методической основой проведенных комплексных исследований является анализ и обобщение литературных источников, посвященных изучению особенностей и термобарических свойств газовых гидратов, аналитические расчеты и лабораторные эксперименты по затратам тепловой энергии для эффективного разложения газогидратов, экспериментальные исследования процесса гидратообразования и диссоциации газогидратных залежей неоднородной структуры.

Результаты. Обоснованы параметры формирования и стабильного существования газогидратов в природных условиях, что необходимо учитывать при разработке газогидратных месторождений. Проанализированы существующие классификации залежей газовых гидратов в осадочных породах. Установлены закономерности процесса диссоциации газогидратных залежей и получения газа метана в зависимости от процентного содержания породных включений. Определены объемы зон разложения и выход газа из неоднородных газогидратных залежей. Рассчитано количество тепловой энергии, которую необходимо затратить для получения $1000 \mathrm{M}^{3}$ гидратного газа при разработке газогидратных месторождений.

Научная новизна. Установлено, что затраты тепловой энергии на протекание процесса диссоциации для получения газа метана изменяются по параболической зависимости с увеличением доли породных включений в газогидратной залежи. Разработана новая классификация газогидратных залежей по содержанию породных включений и количеству затраченной тепловой энергии на диссоциацию газогидрата.

Практическая значимость. Результаты исследований с достаточной для практического применения точностью могут использоваться при разработке газогидратных залежей Черного моря с целью получения природного газа. Выявленные зависимости выхода газа метана от доли породных включений являются инструментарием для определения эффективной области применения технологий разработки залежей газовых гидратов.

Ключевые слова: газогидратная залежь, неоднородность, классификация, породные включения, диссоциация, затраты энергии

Рекомендовано до публікації докт. техн. наук I.А.Ковалевською. Дата надходження рукопису 13.01.17. 